Ethiopian Journal of Environmental Studies \& Management 9 (2): 167 - 178, 2016.

ISSN:1998-0507

doi: http://dx.doi.org/10.4314/ejesm.v9i2.5

Submitted: November 04, 2015

Accepted: March 03, 2016

\title{
BACTERIOLOGICAL AND PHYSICOCHEMICAL ANALYSIS OF WASTE WATER FROM FISH PONDS
}

\author{
*SULE, I.O., AGBABIAKA, T.0., AHMED, R.N., SALIU, B.K. AND OLAYINKA, K. J. \\ Department of Microbiology, Faculty of Life Sciences, University of Ilorin, PMB 1515 Ilorin, \\ Nigeria
}

\begin{abstract}
Rearing of fish especially catfish is very common in many communities in Nigeria and the wastewater from these fish ponds are often discharged into the surrounding drains. Assessment of the bacteriological and physicochemical characteristics of ten freshwater fish ponds stocked with African catfish (Clarias gariepinus) was conducted within llorin metropolis. The results of physicochemical properties of the water samples showed that the $\mathrm{pH}$, total hardness, salinity, and suspended solid ranged from $6.77-8.43,65-124 \mathrm{mg} / \mathrm{l}, 7.02-10.062 \mathrm{~g} / \mathrm{l}$, and $0.012-0.128 \mathrm{~g} / 100 \mathrm{ml}$ respectively. The bacterial count, total coliform, and faecal coliform count of the wastewater ranged from $4.0 x$ $10^{3}-6.7 \times 10^{5} \mathrm{cfu} / \mathrm{ml}$, nil to $2 \times 10^{4} \mathrm{cfu} / \mathrm{ml}$, and nil to $1 \times 10^{3} \mathrm{cfu} / \mathrm{ml}$ respectively. The bacterial species isolated from the ponds were Escherichia coli, Staphylococcus sp., Staphylococcus aureus, Aeromonas hydrophila, Staphylococcus saprophyticus, Chromobacterium sp, Micrococcus sp., Micrococcus kristinae, Providencia sp., and Listeria sp. The antibiotics susceptibility testing of the bacterial isolates were determined using the disc method. All the isolates exhibited multiple antibiotic resistance (MAR). It can be concluded from this study that there is need to monitor the quality of wastewater from the fish ponds before being discharged into the environment since potential pathogens were isolated and most of these isolates were multiple antibiotic resistant. This study is of socioeconomic significance in the sense that while the farmers are able to raise their fish in the ponds and derive their livelihood, they are being cautioned on the need to treat their waste water before being discharged into the receiving water body.
\end{abstract}

Key Words: Wastewater, Fish pond, Catfish, Assessment, Antibiotic resistance

\section{Introduction}

Wastewater comprises liquid waste such as sewage, oil and chemicals. These waste waters contain a wide range of potential contaminants. Waste water contains offensive and potentially dangerous substances which are mostly of anthropogenic origin and causing pollution and contamination of receiving water bodies (Ikpi and Offem, 2011). Fortunately, water can naturally renew and cleanse itself via various physical methods: dilution, sunlight, aeration, flocculation, sedimentation, biological degradation (decomposition), predatory activities of microorganisms etc (Hanelore, 2013). This process of renewal is called selfpurification and large bodies of water is said to possess self-purifying capacity (Bitton, 2005). Contamination of water is a serious environmental problem as it affects the different uses of the water. The use of indicator bacteria such as faecal coliforms in water quality determination is widely applied. Coliforms and Escherichia coli are of great importance among bacterial indicators used in water quality assessment (Torimiro et al., 2014).

*Corresponding Author: Sule, I.O.

Email: suleism@gmail.com 
One of the prominent uses of surface water such as river, pond, run-off etc is in aquaculture which has contributed immensely to the food sector and reduced the risk of fishes at the brink of extinction due to excessive catch in lakes and oceans (Tidwell and Allan, 2001). More than onefourth of all animal protein consumed by man is aquatic in origin (FAO, 2000). Aquaculture has been practiced in many Asian countries for centuries, but is a new form of agriculture in many African and Latin American countries. It is defined as the cultivation of animals and plants in aquatic environments. Aquaculturists manipulate certain components of the environment to achieve greater control on production of aquatic organisms (Purdom, 1996).

In Nigeria, the rearing of African catfish (Clarias gariepinus) is helping in the provision of food and its usefulness cannot be over-emphasized as the demand for fish is expanding rapidly throughout the world (Ugwuba and Chukwuji, 2010).

There is an intricate relationship between the fish, their biotic and abiotic environments and changes in one component may reflect and affect the other (Wurt, 2000). Pond water or water used in intensive fish rearing contain many microorganisms which could be pathogenic or opportunistic pathogen to fish, human, and planktons (Zmyslowska et al., 2003). These contaminating microorganisms have been attributed to questionable water quality which can be traced to the water sources and high stocking densities (Okpokwasili and Akujobi, 1996). Water sources for earthen ponds are usually untreated surface water runoffs from streams, rivers, lakes, stored waters while underground water source is being utilized for most concrete ponds.
Water from underground sources such as a well is pumped and stored in storage tank which is used to refill the ponds when the water is to be changed at intervals of about 3-5 days.

The feed used for fish in these ponds contain organic materials and introduces a wide variety of microorganisms into the ponds. Omojowo and Omojasola (2013) isolated six bacterial pathogens: E. coli, E. coli 0157:H7, Shigella dysenteriae, Staphylococcus aureus, Salmonella typhi, and Aeromonas hydrophila from Cow dung used as feed in the fish pond. The microbial flora of a cultivated fish is a reflection of its aqueous environment (Sugita et al., 1985; Oni et al., 2013).

Freshwater fish in ponds commonly suffer from bacterial diseases such as various kinds of skin ulcerations, albinoderma, erythroderma, furunculosis, and verticle-scale disease, primarily caused by Aeromonas sp. and Pseudomonas sp. (Das, 2004). Some of these diseases were reported to be most severe during the dry season, when declining water quality is a problem. In Arizona, significant mortalities of cultured tilapia resulted from infection with a salt-tolerant strain of the bacterium Aeromonas hydrophilia (Llobrera and Gacutan, 1987).

Some prevalent pathogenic bacteria of milkfish and tilapia isolated in Taiwan include species of the genera: Aeromonas, Edwardsiella, Flavobacterium, Pseudomonas, and Streptococcus (Suresh and Lin, 1992). A ricketssia-like bacterium has also been identified as a causative agent for disease outbreaks in tilapia cultured in Taiwan.

The spread of multiple antibioticresistant pathogenic bacteria have been recognised by the World Organization for Animal Health (WOAH), the Food and Agriculture Organization (FAO) and the 
World Health Organization (WHO) as a serious global human and animal health problem. The development of bacterial antimicrobial resistance is neither an unexpected nor a new phenomenon. It is, however, an increasingly troublesome situation because of the frequency with which new emerging resistance phenotypes are occurring among many bacterial pathogens and even commensal organisms. Resistance has been observed to essentially all of the antimicrobial agents currently approved for use in human and veterinary clinical medicine. The scope of this research is to elucidate the bacterial contaminants in waste water from fish ponds as well as their antibiotics susceptibility patterns.

It is common to see many fish ponds within our community raising different types of fish especially catfish. The waste water from these fish ponds are often discharged into the surrounding drains. Hence, this study is conducted to determine the quality of this waste water in order to protect the environment, plant, animal and man.

The aims and objectives of this research were to determine the physicochemical and bacteriological characteristics of waste water from fish ponds; isolate, identify and determine the occurrence of the bacterial species; and the antibiotics susceptibility patterns of the bacterial isolates.

\section{Methodology}

\section{Study Area}

Wastewater samples were collected from some fish ponds within Ilorin metropolis. These were 8 earthen ponds: TJ fish farm I, Asa dam I, Tanke, Ilesanmi, Osere I, TJ fish farm II, Asa dam II, and Osere II; and 2 concrete ponds: G.R.A, and Phoenix.

\section{Sample Collection}

The wastewater was collected aseptically into a sterile amber bottle at a depth $10-15 \mathrm{~cm}$ from the surface of the water (Njoku et al., 2015). The water samples were transported in black polythene bag immediately for analysis. The sampling was done during the months of November 2014 to January 2015 between $8-10$ am.

\section{Determination of $p H$}

The $\mathrm{pH}$ of the water sample was determined using a digital Denver $\mathrm{pH}$ meter model 20 with glass electrode. This was done according to standard method (APHA, 1998).

\section{Determination of Suspended Solid}

This was determined by filtration method using Whatman's filter papers (Dubey and Maheshwari, 2005).

Determination of Salinity Content of the Water Samples

This was determined using argentiometric titration according to $\mathrm{BP}$, 1993.

\section{Determination of Total Hardness}

This was determined using complexometric titration as described by Dubey and Maheshwari (2005).

\section{Bacteriological Analysis}

The bacterial count of the wastewater was determined using pour plate technique while spread plate methods were used for the total and faecal coliform counts. The media used were nutrient agar, MacConkey agar, and eosin methylene blue agar for bacterial count, total coliform, and faecal coliform count respectively (Fawole and Oso, 2007; Willey et al., 2011).

\section{Characterization and Identification of Bacterial Isolates}

The isolated bacteria were characterized based on their colonial morphology, cellular morphology and 
biochemical properties and then identified by making reference to standard textbooks (Mac Faddin, 1980; Cowan and Steel, 1985).

\section{Antimicrobial Susceptibility Test}

The broth culture of each isolate was standardized using 0.5 McFarland standard. Then, set plate of sterile Mueller Hinton agar was inoculated with the standardized test organism and the antibiotic disc was placed on the inoculated medium. The medium was incubated at $37^{\circ} \mathrm{C}$ for 24 hours. After incubation, the plate was observed for zones of inhibition around each of the antibiotics. The diameter of the zone of inhibition was then measured in millimeter (mm) (CLSI, 2005; Brown and MacGowan, 2010). Gram positive antibiotic disc was used for Gram positive organism while Gram negative antibiotic disc was used for Gram negative organism.

\section{Multiple Antibiotics Resistance (MAR) Indexing of Isolates}

The multidrug resistance of the bacterial isolates were analyzed using the multiple antibiotic resistance (MAR) index. The multiple antibiotic resistance (MAR) index was defined as $a / b$ where ' $a$ ' represent the number of antibiotics to which the isolate was resistant to and ' $b$ ' the number of antibiotics to which the isolate was exposed (Chitanand et al., 2010).

\section{Data Analysis}

The data were analysed using SPSS 15.0 package. All data are mean of three replicates. The mean, range and standard deviation of each parameter was determined. The means were separated using Duncan's Multiple Range test (SPSS, 2010).

\section{Results}

Physicochemical Parameters of Waste Water from Fish Ponds

The physicochemical properties of the wastewater showed a $\mathrm{pH}$ range of 6.77 8.43 , total hardness $65-124 \mathrm{mg} / \mathrm{l}$, salinity content $7.02-10.06 \mathrm{~g} / \mathrm{l}$, and suspended solid $0.012-0.128 \mathrm{~g} / 100 \mathrm{ml}$ (Table 1).

Bacteriological Counts of Waste Water from Fish Ponds

The bacterial count, total coliform and faecal coliform of the wastewater ranged from $4.0 \times 10^{3}-6.7 \times 10^{5} \mathrm{cfu} / \mathrm{ml}$, nil to $2 \times$ $10^{4} \mathrm{cfu} / \mathrm{ml}$, and nil to $1 \times 10^{3} \mathrm{cfu} / \mathrm{ml}$ respectively (Table 2 ).

\section{Bacterial isolates and their occurrence}

Ten bacteria species were identified (Table 3) and their occurrences was as presented in Table 4. This comprises both Gram positive and Gram negative bacteria.

Antibiotic susceptibility testing (AST) of bacterial isolates

All the Gram positive bacteria were susceptible to Ofloxacin but resistant to Ceftazidime, Cefuroxime, AmoxycillinClavulinate antibiotics. Similarly, all the Gram negative bacteria were susceptible to Nitrofuratoin, Ofloxacin, Ciprofloxacin, but resistant to Amoxycillin-Clavulinate, Ampicillin, Cefuroxime, Ceftazidime antibiotics (Table 5). All the isolates showed multiple antibiotic resistance (MAR) (Table 6). The isolates with MAR index values higher than 0.2 were considered multiple resistant (Chitanand et al., 2010). 
Table 1: Physicochemical characteristics of wastewater from the fish ponds

\begin{tabular}{lclll}
\hline Sample & $\mathrm{pH}$ & $\begin{array}{l}\text { Salinity content } \\
(\mathrm{g} / \mathrm{l})\end{array}$ & $\begin{array}{l}\text { Suspended solid } \\
(\mathrm{g} / 100 \mathrm{ml})\end{array}$ & $\begin{array}{l}\text { Total Hardness } \\
(\mathrm{mg} / \mathrm{l})\end{array}$ \\
\hline T J fish farm I * & $8.02^{\mathrm{g}} \pm 0.02$ & $9.59^{\mathrm{ef}} \pm 0.05$ & $0.128^{\mathrm{g}} \pm 0.002$ & $124^{\mathrm{e}} \pm 4.0$ \\
T J fish farm II $*$ & $8.43^{\mathrm{h}} \pm 0.03$ & $10.06^{\mathrm{f} \pm} 1.0$ & $0.062^{\mathrm{b}} \pm 0.001$ & $90^{\mathrm{d}} \pm 5.0$ \\
Ilesanmi $^{\mathrm{b}}$ & $7.34^{\mathrm{e}} \pm 0.04$ & $8.48^{\mathrm{bc}} \pm 0.08$ & $0.075^{\mathrm{c}} \pm 0.003$ & $87^{\mathrm{c}} \pm 4.0$ \\
Tanke $*$ & $7.25^{\mathrm{d}} \pm 0.03$ & $8.66^{\mathrm{bc}} \pm 0.06$ & $0.084^{\mathrm{d}} \pm 0.002$ & $89^{\mathrm{d}} \pm 5.0$ \\
G.R.A ** & $8.04^{\mathrm{g}} \pm 0.02$ & $8.19^{\mathrm{b}} \pm 0.03$ & $0.013^{\mathrm{a}} \pm 0.002$ & $65^{\mathrm{a}} \pm 5.0$ \\
Phoenix ** & $8.04^{\mathrm{g}} \pm 0.01$ & $7.02^{\mathrm{a}} \pm 0.05$ & $0.012^{\mathrm{a}} \pm 0.001$ & $66^{\mathrm{a}} \pm 6.0$ \\
Osere I $*$ & $6.77^{\mathrm{a}} \pm 0.03$ & $9.71^{\mathrm{ef}} \pm 0.03$ & $0.101^{\mathrm{f}} \pm 0.001$ & $74^{\mathrm{b}} \pm 4.0$ \\
Asa dam I $*$ & $7.46^{\mathrm{f}} \pm 0.02$ & $9.01^{\mathrm{cd}} \pm 0.04$ & $0.079^{\mathrm{c}} \pm 0.003$ & $80^{\mathrm{b}} \pm 5.0$ \\
Osere II $*$ & $7.19^{\mathrm{c}} \pm 0.03$ & $9.36^{\mathrm{de}} \pm 0.04$ & $0.094^{\mathrm{e}} \pm 0.004$ & $82^{\mathrm{bcd}} \pm 4.0$ \\
Asa dam II $*$ & $6.83^{\mathrm{b}} \pm 0.03$ & $8.89^{\mathrm{cd}} \pm 0.07$ & $0.096^{\mathrm{e}} \pm 0.003$ & $86^{\mathrm{cd}} \pm 4.0$ \\
\hline
\end{tabular}

*, Earthen pond; **, Concrete pond

Mean followed by the same superscript within the same column are not significantly different at $\alpha=$ 0.05 based on Duncan's multiple range test (DMR).

Table 2: Bacteriological counts of wastewater from the fish ponds

\begin{tabular}{llll}
\hline Sample & $\begin{array}{l}\text { Bacterial count } \\
(\mathrm{cfu} / \mathrm{ml}) \times 10^{3}\end{array}$ & $\begin{array}{l}\text { Total coliform count } \\
(\mathrm{cfu} / \mathrm{ml}) \times 10^{3}\end{array}$ & $\begin{array}{l}\text { Faecal coliform } \\
(\mathrm{cfu} / \mathrm{ml})\end{array}$ \\
\hline T J fish farm I * & $300^{\mathrm{f}} \pm 20$ & $20^{\mathrm{c}} \pm 2$ & $0^{\mathrm{a}} \pm 0$ \\
T J fish farm II $*$ & $200^{\mathrm{e}} \pm 10$ & $0^{\mathrm{a}} \pm 0$ & $0^{\mathrm{a}} \pm 0$ \\
Ilesanmi $^{*}$ & $13^{\mathrm{a}} \pm 2$ & $0^{\mathrm{a}} \pm 0$ & $0^{\mathrm{a}} \pm 0$ \\
Tanke $*$ & $4.0^{\mathrm{a}} \pm 1$ & $0^{\mathrm{a}} \pm 0$ & $0^{\mathrm{a}} \pm 0$ \\
G.R.A $* *$ & $66^{\mathrm{b}} \pm 3$ & $0^{\mathrm{a}} \pm 0$ & $0^{\mathrm{a}} \pm 0$ \\
Phoenix $* *$ & $78^{\mathrm{bc}} \pm 4$ & $0^{\mathrm{a}} \pm 0$ & $0^{\mathrm{a}} \pm 0$ \\
Osere I $*$ & $180^{\mathrm{d}} \pm 20$ & $0^{\mathrm{a}} \pm 0$ & $0^{\mathrm{a}} \pm 0$ \\
Asa dam I $*$ & $19^{\mathrm{a}} \pm 2$ & $2.0^{\mathrm{b}} \pm 0$ & $1.0^{\mathrm{b}} \pm 0$ \\
Osere II $*$ & $670^{\mathrm{g}} \pm 20$ & $0^{\mathrm{a}} \pm 0$ & $0^{\mathrm{a}} \pm 0$ \\
Asa dam II $*$ & $89^{\mathrm{c}} \pm 20$ & $2.0^{\mathrm{b}} \pm 0$ & $1.0^{\mathrm{b}} \pm 0$ \\
\hline
\end{tabular}

*, Earthen pond; **, Concrete pond

Mean followed by the same superscript within the same column are not significantly different at $\alpha=$ 0.05 based on Duncan's multiple range test (DMR). 


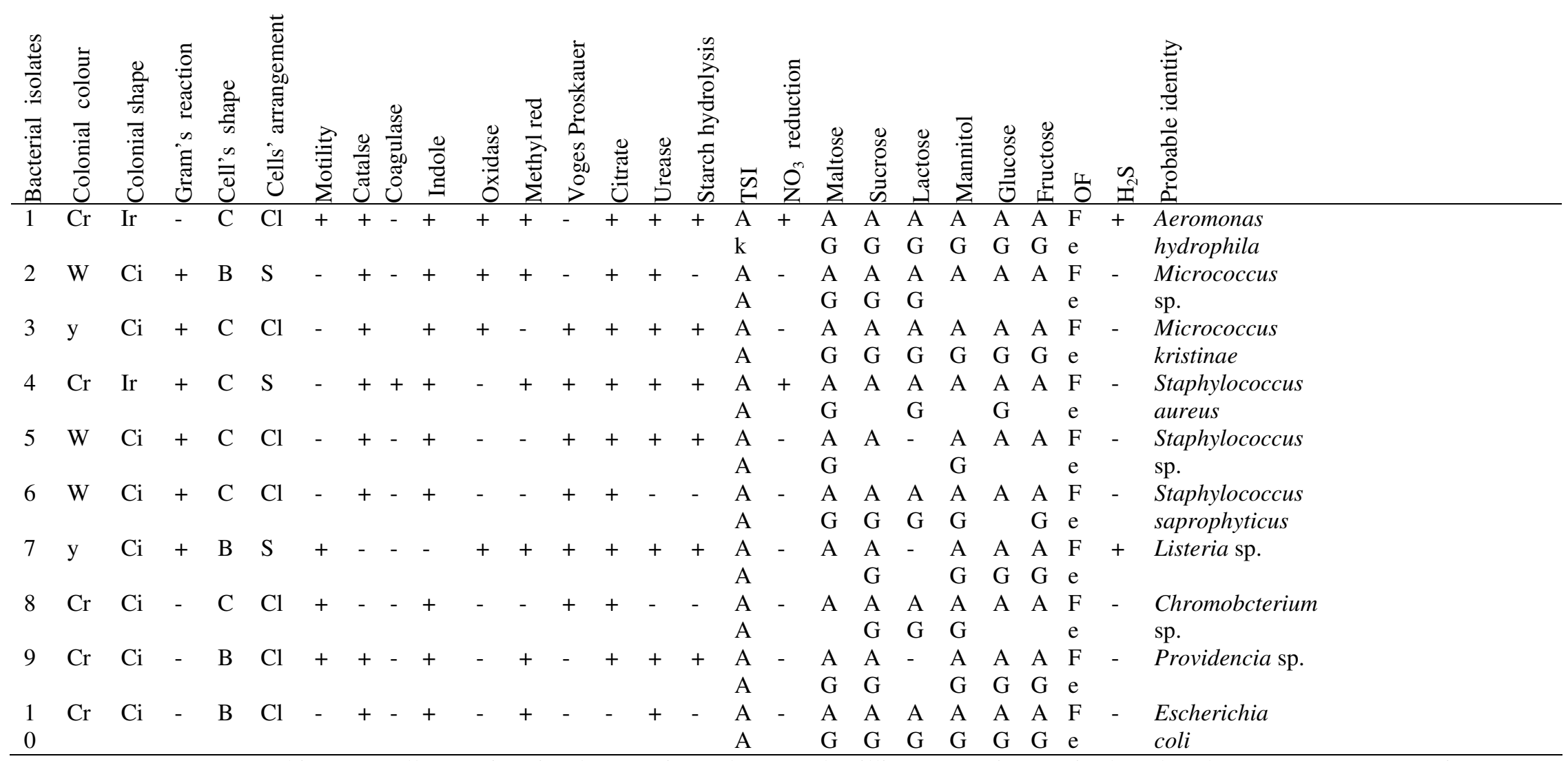

Key: $\mathrm{Cr}=$ cream; $\mathrm{W}=$ white; $\mathrm{y}=$ yellow; $\mathrm{Ci}=$ circular; $\mathrm{Ir}=$ irregular; $; \mathrm{B}=$ bacilli; $\mathrm{C}=$ cocci $\mathrm{S}=$ Single $; \mathrm{Cl}=$ cluster $\mathrm{Fe}=\mathrm{Fermentative} ; \quad-=$ negative reaction; + = positive reaction; $\mathrm{OF}=$ Oxidation-Fermentation; $\mathrm{AK}=$ Acid/Alkaline reaction; $\mathrm{AA}=\mathrm{Acid} / \mathrm{Acid} \mathrm{reaction} ; \mathrm{AG}=\mathrm{Acid}$ and gas; $\mathrm{A}=$ Acid only 
Table 4: Occurrence of bacterial isolates in wastewater from the fish ponds

\begin{tabular}{|c|c|c|c|c|c|c|c|c|c|c|}
\hline Bacterial isolates & 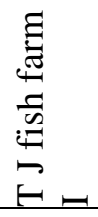 & 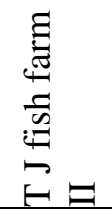 & 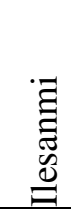 & $\begin{array}{l}\mathscr{y} \\
\stackrel{\tilde{E}}{E}\end{array}$ & 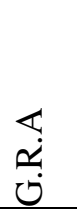 & 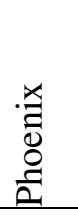 & $\begin{array}{l}\overrightarrow{0} \\
\ddot{0} \\
0\end{array}$ & 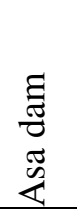 & $\begin{array}{l}= \\
0 \\
0 \\
0 \\
0 \\
0\end{array}$ & 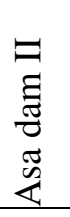 \\
\hline Aeromonas hydrophila & + & + & + & + & + & + & - & - & - & - \\
\hline Micrococcus sp. & - & + & + & - & - & + & - & - & - & - \\
\hline Micrococcus kristinae & - & - & + & + & + & - & + & + & + & + \\
\hline Staphylococcus aureus & - & - & - & + & - & - & - & + & + & + \\
\hline Staphylococcus sp. & + & + & - & - & - & - & + & + & + & + \\
\hline Listeria sp. & - & - & - & - & - & + & - & - & - & - \\
\hline Chromobacterium sp. & - & - & + & + & + & + & + & + & - & + \\
\hline $\begin{array}{l}\text { Staphylococcus } \\
\text { saprophyticus }\end{array}$ & - & - & + & - & - & - & - & - & + & + \\
\hline Providencia sp. & + & - & + & - & - & + & - & + & + & + \\
\hline Escherichia coli & - & - & - & - & - & - & - & + & - & + \\
\hline
\end{tabular}

Table 5: Antibiotics susceptibility pattern of bacterial isolates

\begin{tabular}{lcccccccc}
\hline Bacterial isolates & & \multicolumn{8}{c}{ Antibiotics } \\
\hline Gram positive: & CAZ & CRX & GEN & CTR & ERY & CXC & OFL & AUG \\
\hline Micrococcus sp. & - & - & - & - & - & - & $+(10)$ & - \\
$\begin{array}{l}\text { Micrococcus } \\
\text { kristinae }\end{array}$ & - & - & $+(13)$ & $+(11)$ & $+(17)$ & - & $+(21)$ & - \\
$\begin{array}{l}\text { Staphylococcus } \\
\text { aureus }\end{array}$ & - & - & $+(12)$ & $+(5)$ & - & - & $+(9)$ & - \\
$\begin{array}{l}\text { Staphylococcus } \text { sp. } \\
\text { Listeria } \text { sp. }\end{array}$ & - & - & - & $+(11)$ & - & - & $+(20)$ & - \\
$\begin{array}{l}\text { Staphylococcus } \\
\text { saprophyticus }\end{array}$ & - & - & - & $+(9)$ & - & - & $+(25)$ & - \\
\hline Gram negative: & CAZ & CRX & GEN & CPR & OFL & AUG & NIT & AMP \\
\hline $\begin{array}{l}\text { Aeromonas } \\
\text { hydrophila }\end{array}$ & - & - & $+(12)$ & $+(20)$ & $+(21)$ & - & $+(23)$ & - \\
$\begin{array}{l}\text { Chromobacterium } \\
\text { sp. }\end{array}$ & - & - & $+(13)$ & $+(21)$ & $+(21)$ & - & $+(23)$ & - \\
$\begin{array}{l}\text { Providencia } \text { sp. } \\
\text { Escherichia coli }\end{array}$ & - & - & - & $+(20)$ & $+(20)$ & - & $+(22)$ & - \\
\hline
\end{tabular}

+ , presence of inhibition; -, absence of zone of inhibition; ( ), diameter of zone of inhibition (mm);

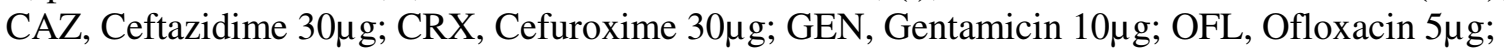

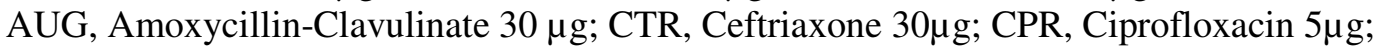

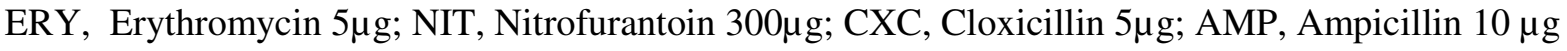


Table 6: Multiple antibiotics resistance (MAR) of the bacterial isolates

\begin{tabular}{llll}
\hline Bacterial isolates & $\begin{array}{l}\text { Number of antibiotics } \\
\text { resistant to (a) }\end{array}$ & $\begin{array}{l}\text { Number of antibiotics } \\
\text { used (b) }\end{array}$ & $\begin{array}{l}\text { MAR Index } \\
\text { (a/b) }\end{array}$ \\
\hline Aeromonas hydrophila & 4 & 8 & 0.50 \\
Micrococcus sp. & 7 & 8 & 0.875 \\
Micrococcus kristinae & 4 & 8 & 0.50 \\
Staphylococcus aureus & 5 & 8 & 0.625 \\
Staphylococcus sp. & 6 & 8 & 0.75 \\
Listeria sp. & 6 & 8 & 0.75 \\
Chromobacterium sp. & 4 & 8 & 0.5 \\
Staphylococcus saprophyticus & 7 & 8 & 0.875 \\
Providencia sp. & 5 & 8 & 0.625 \\
Escherichia coli & 2 & 8 & 0.25 \\
\hline
\end{tabular}

\section{Discussion}

Eighty percent of the fish ponds used in this study were earthen ponds. Most of the concrete fish ponds' wastewater have higher $\mathrm{pH}$ (tend to be alkaline) when compared with the earthen ponds' wastewater. This could be due to dissolution of ions from the soil into the fish pond's water.

The optimal water hardness necessary for fish to thrive is dependent on the species of fish. Most fish grow well over a wide range of hardness values. The total hardness values in this study is between 65 - $124 \mathrm{mg} / \mathrm{l}$ and falls within the recommended standard of $60-130 \mathrm{mg} / \mathrm{l}$ for fish culture and within the permissible $100 \mathrm{mg} / \mathrm{l}$ hardness for catfish (Department of Water Affairs and Forestry, 1996).

The earthen ponds have higher level of suspended solid when compared to concrete ponds which is due to the soil sediments, disturbances when water is to be changed, agitation by the fish during feeding and a hunger protest. Earthen ponds mimic the natural habitat of these fishes with characteristics which include direct exposure to sunlight, presence of soil beneath the water, presence of other aquatic plants e.g. zooplankton, algae, diatoms, phytoplankton, water dries owing to natural causes (evaporation).

Salinity is among the most important factors and exerts various effects on the vitality of microorganisms. The differences in the salinity are attributed to the increase in the evaporation rate (Torimiro et al., 2014). Salinity content in earthen ponds were slightly higher owing to increased evaporation rate compared to that in concrete ponds and some of the water in earthen ponds infiltrate into the soil resulting into water loss.

The result of the bacteriological analysis showed that the bacterial count varied with location and this may be due to differences in management practices resulting in different level of organic loads in the pond system from the diet used in feeding the fish (Oni et al., 2013).

The source of microorganisms could also be traced to sources of water fed into the pond. Well water is expected to be of good quality when used for the pond than water from river surface runoff or stream. Also the frequency of change of the water especially in concrete ponds influences the microbial load. Concrete ponds are completely discharged and refilled with fresh water while earthen ponds uses a topping system where more water is added in order to maintain specific volume or 
water levels. It was observed that the microbial load in earthen ponds were considerably higher than that of concrete ponds. In a similar study, Nzeh and Udeze (2012) obtained bacterial counts which ranged from $1.0 \times 10^{4}-2.0 \times 10^{4} \mathrm{cfu} / \mathrm{ml}$ and $9.0 \times 10^{3}-1.2 \times 10^{4} \mathrm{cfu} / \mathrm{ml}$ in earthen and concrete ponds respectively.

The persistence of pathogens in the water environment is considered as one of the crucial factors for infection transmission in terms of acute outbreaks of disease. This study revealed the presence of Escherichia coli, Aeromonas hydrophila, Micrococcus kristinae, Micrococcus sp., Staphylococcus sp., Staphylococcus saprophyticus, Staphylococcus aureus, Listeria sp., Chromobacterium sp., and Providencia sp. in the fish ponds water and this may pose a threat to the health of the fishes and consumers. It was found that Gram negative bacteria genera predominate and this is in agreement with findings reported by Molokwu and Okpokwasili, (2002), Akinwale et al. (2007), Khunthongpan et al. (2013), and Njoku et al. (2015) in their study on the diversity of microflora of fish pond water. Furthermore, Elsaidy et al. (2015) isolated E. coli, coliforms and Salmonella sp. from water and fish being fed with raw and fermented manure. The recovery of Escherichia coli in two of the fish ponds could suggest a possible faecal contamination of the fish ponds. The faecal material may be as a result of fertilization of the ponds with animal manure which is discharged directly into the fish ponds, or excreted by the fish into the ponds (Ayulo et al., 1994; Omojowo and Omojasola, 2013).

All the organisms were susceptible to Ofloxacin which can be used for treating infections in both humans and animals at appropriate concentrations. In a similar study, Morrison (2006) detected oxacillin resistance in Staphylococcus sciuri group. The detection of pathogenic bacteria that are multi-drug resistant that is having multiple antibiotics resistance (MAR) index values higher than 0.2 call for the need for formulation and implementation of code of practice for fish farmers. This is to ensure appropriate fish management and prevention of transmission of potential pathogens which is important in the part of food safety plan.

\section{Conclusion}

It can be concluded from this study that there is need to monitor the quality of wastewater from the fish ponds before being discharged into the environment since potential pathogens were isolated and most of these isolates were multiple antibiotics resistant.

\section{Recommendation}

It is recommended that microbiological analysis and physicochemical examination of wastewater or fish for signs of possible infections should be conducted on a regular basis. The ministry of agriculture should ensure that the fish farmers are supplied with healthy fry for their stock. Good quality water such as well or borehole should be used in the fish pond rather than water from questionable sources such as river, stream, and surface runoff. The fish feeds should be sourced from reputable manufacturers'. Water in the fish pond should be changed completely at regular intervals. Concrete ponds should be used for rearing of fish rather than earthen ponds. Waste water should be treated either by physical methods which involve filtration through slow sand filters, rapid sand filters, sand beds or chemical methods such as addition of disinfectants eg chlorine before final disposal into surrounding drains. 


\section{Acknowledgements}

The authors acknowledge the cooperation received from the owners of the fish ponds where water samples were collected.

\section{Reference}

Akinwale, M.M.A., Keke, R.I. and Egenonu, C. (2007). Bacterial microflora of African catfish (Clarias gariepinus) juveniles raised under fish cum pig integrated farming system in fresh water earthen ponds during the dry season. Nig. J. Fisheries, 4(2): 91 - 104.

APHA (1998). Standard Methods for the Examination of Water and Wastewater, $20^{\text {th }}$ edition. American Public Health Association, Washington DC, ISBN: 0-30909122-5

Ayulo, A.M., Machado, R.A. and Scussel, V.M. (1994). Enterotoxigenic Escherichia coli and Staphylococcus aureus in fish and seafood from the southern region of Brazil. Int. J. Food Microbiol., 24: 171 - 178.

Bitton, G. (2005). Waste water Microbiology, $3^{\text {rd }}$ edition, John wiley and Sons, Inc., Hoboken, New Jersey, USA. P. 400

BP (1993). British pharmacopeia, volume I, International edition, HMSO publication centre, London pp.604 605

Brown, D. and MacGowan, A. (2010). Harmonization of antimicrobial susceptibility testing breakpoints in Europe: implications for reporting intermediate susceptibility. $J$. Antimicrob. Chemother., 65: 183 185.

Chitanand, M.P., Kadam, T.A., Gyananath, G., Totewad, N.D. and Balhal, D.K. (2010). Multiple antibiotic resistance indexing of coliforms to identify high risk contamination sites in aquatic environment. Indian Journal of Microbiology 50(2): 216 - 220. Doi:10.1007/s 12088-010-042-9

CLSI (2005). Performance standards for antimicrobial susceptibility testing. Fifteenth informational supplement, M100-S15, vol. 25, No. 1.Clinical and Laboratory Standard Institute, Wayne, $\mathrm{Pa}$.

Cowan S.T. and Steel, K.J. (1985). Manual for the identification of medical bacteria. $4^{\text {th }}$ edition, Cambridge University Press, London. 217pp.

Das, B.K. (2004). Bacterial diseases of fish and their control. In: Swain P., Sahoo P.K. Das B.K. Disease Diagnosis and Health Management of Freshwater Fish and Shellfish. Bhubaneshwar, Central Institute of Freshwater Aquaculture, 45 - 52.

Department of Water Affairs and Forestry (1996). South African Water quality Guidelines, Agricultural use: Aquaculture $2^{\text {nd }}$ Edition 6, 170pp.

Dubey, R.C. and Maheshwari, D.K. (2005). Practical Microbiology. S.Chand and company Ltd., New Delhi. 352pp.

Elsaidy N., Abouelenenien, F. and Kirella, G.A.K. (2015). Impact of using raw or fermented manure as fish feed on microbial quality of water and fish. The Egyptian Journal of Aquatic Research 41(1):93 - 100

FAO (2000). The State of World Fisheries and Aquaculture. Food and Agricultural Organization, Rome, Italy.

Fawole, M.O. and Oso, B.A. (2007). Laboratory Manual of Microbiology. Spectrum Books Limited, Ibadan, $123 \mathrm{pp}$. 
Hanelore, M. (2013). The process of self purification in the rivers. $13^{\text {th }}$ SGEM Geo conference on water resources, forest, marine and ocean ecosystems. Pp. $409-416$

Ikpi, G. and Offem, B. (2011). Bacterial infection of mudfish Clarias gariepinus (Siluriformes: Clariidae) fingerlings in tropical nursery ponds. Rev. Biol. Trop. 59: 751 - 759.

Khunthongpan, S., Sumpavapol, P., Tanasupawat, S., Benjakul, S. and H-Kittikun, A. (2013). Providencia thailandensis sp. nov., isolated from seafood processing wastewater, $J$. Gen. Appl. Microbiol. 59: 185 - 190.

Llobrera, A.T. and Gacutan, R.Q. (1987). Aeromonas hydrophila associated with ulcerative disease epizootic in Laguna de Bay, Philippines. Aquaculture 67(3/4): 273 - 278

Mac Faddin, J.F. (1980). Biochemical tests for identification of medical bacteria. $2^{\text {nd }}$ edition, Williams and Wilkins Baltimore, USA. 527pp.

Molokwu, C.N. Okpokwasili, G.C. (2002). Microbial flora of Clarias gariepinus in the early stages of development. Trop. Freshwater Biol., 11: 91 - 100.

Morrison, D. (2006). Evaluation of phenotypic and molecular methods for detection of oxacillin resistance in members of the Staphylococcus sciuri group. J. Clin. Microbiol., 44:934 - 937

Njoku, O.E., Agwa, O.K. and Ibiere, A.A. (2015). An investigation of the microbiological and physicochemical profile of some fish ponds water within Niger Delta of Nigeria. African Journal of Food Science, 9(3):155-162.

Doi:10.58977/ajfs2014.1208
Nzeh, C.G. and Udeze, A.O. (2012). Microbial survey of fish ponds and mineral composition of Clarias gariepinus in Ilorin metropolis. International Journal of Biology and Chemical Sciences 6(2): 832 - 837

Okpokwasili, G.C. and Akujobi, T.C. (1996). Bacteriological indicators of tropical water quality. Environmental Toxicology 11: 77 - 81. Doi: 10.1002/(SICI)10982256(1996)11:2<77::AIDTOX >3.0.CO;2-5

Omojowo, F.S. and Omojasola, P.F. (2013). Antibiotic resistance pattern of bacterial pathogens isolated from Cow dung used to fertilize Nigerian fish ponds. Notulae Scientia Biologicae, 5(1): 15 - 19

Oni, T.A., Olaleye, V.E. and Omafuvbe, B.O. (2013). Preliminary studies on associated bacterial and fungal load of artificially cultured Clarias gariepinus Burchell 1822 fingerlings. Ife J. Sci. 15 (1): 9 - 16.

Purdom, C.E. (1996). Ministry of Agriculture, Fisheries, Food and Fish cultivation. Res. Lab. Leaflet. $35: 1-28$.

SPSS (2010). Statistical Package for Social Scientists 15.0 for window. www.spss.com

Sugita, H., Fushino, T., Oshima, K. and Deguchi, Y. (1985). Microflora in the water and sediment of freshwater culture ponds. Bulletin of the Japanese Society for Scientific Fisheries, 51:91 - 97

Suresh, A.V. and Lin, C.K. (1992). Tilapia culture in saline waters: A review. Aquaculture 106:201 - 226

Tidwell, J.H. and Allan, G.L. (2001). Fish as food: aquaculture contribution. 
The European Molecular Biology Organization, 2(11): 958 - 963

Torimiro, N., Bebe, P.T., Ogundipe, F.E., Esan, D.M., Aduwo, A.I.

Ugwuba, C.O.A., Chukwuji, C.O. (2010). The economics of catfish production in Anambra state Nigeria.: A profit function Approach. J. Agric. Soc. Sci., 6 (4): 105 - 109.

Willey, J.M., Sherwood, L.M. and Woolverton, C.J. (2011). Prescott Microbiology. $8^{\text {th }}$ edition McGrawHill Companies, New York. 1070pp.

Wurt, W.A. (2000). Sustainable aquaculture in the twenty first
(2014). The bacteriology and physico-chemical analysis of freshwater fish ponds. Int. Res. J. Microbiol., 5(3): 28 - 32 century. Reviews in Fisheries Science, 8:141-150

Zmyslowska, I., Kolman, R. and Krause, J. (2003). Bacteriological evaluation of water, feed and Sturgeon (Acipenser baeri Brandt) fry quality during intensive rearing in cooling water $[\mathrm{J}]$. Archives of Polish Fisheries. 11: 9198. 